\title{
Technology and Innovation Management in Times of Crisis: Problems and Suggestions
}

\author{
M. Hanefi Calp \\ Assoc. Professor, Department of Management Information Systems, \\ Karadeniz Technical University, Trabzon, Turkey \\ mhcalp@ktu.edu.tr
}

\begin{abstract}
The economic, social and technological structures of the countries change in a short time in times of crisis and societies tend to especially towards information and communication technologies. This situation causes the technology, which is already widely used in daily life, to be more dominant in every field. Thus, many activities that are difficult to implement in real life such as identifying, sharing, monitoring, testing, predicting and making decisions, which are needed mostly in times of crisis, can be performed more easily. However, for the successful implementation of these activities, the right technology must be acquired, used and managed at the right time and the technology innovation process must be dynamic. Therefore, at this point, the subject of technology and innovation management comes to the fore. Considering the problems encountered in the management process especially during crisis periods, the importance of this issue is understood more. In this context, the study put forward some suggestions for the importance of technology and innovation management during crisis periods, the risks encountered in this process, threats and problems, and measures to be taken against these problems. The study is thought to be particularly important in terms of being prepared in terms of crisis periods that cause sudden, unpredictable and difficult-to-fix negative results.
\end{abstract}

Keyword-Crisis, Technology, Innovation, Technology, Innovation Management.

\section{INTRODUCTION}

$\mathrm{T}$ ODAY, with the formation of information societies, obtaining, using, sharing and managing information is preferred as a management strategy. Technology is used effectively in this process. It is very important to use the technology resource effectively and efficiently and to create a value for the society [1]. Because technology provides new facilities and opportunities to societies. Thanks to technology, institutions or organizations can perform their duties more easily in cooperation with each other and can access all kinds of information they need faster. However, an important point here is to use the right technologies at the right time and sufficiently. Thus, the technologies used will be a labor force for societies and the competitiveness of institutions will be created [2].

With the development of technology, technological changes occur in line with the needs. These changes affect societies according to their level of development and welfare. It is necessary to monitor the technologies used, to anticipate the technological changes and to adapt to these changes in order to be affected from this situation at the minimum level in the negative sense and at the maximum level in the positive sense. They both lose their competitive power and cannot make the right decisions for their future when businesses providing information and service production cannot adapt to technological innovations or changes. In addition, they may face serious economic and strategic difficulties. With an effective and timely technology management, businesses can prevent damages that may come to them, and realize their production and investments more accurately. Therefore, considering the rapid development of technology, institutions need an effective technology and innovation management [3].

The concept of technology management can be expressed as the planning, development and implementation of technology in order for businesses to achieve their operational and strategic goals. This subject can be thought of as integrating engineering and management science disciplines. It is thought that technology management provides competition for businesses and is effective in creating value. According to the size of the businesses, technological management should ensure that the entire technological infrastructure is compatible with the needs of the institution or personnel [4]. Because societies may face certain risks or threats in their daily life and business life. Some of these risks and threats can cause low negative impact and some of their irreversible impact. Normally, risks with low realization potential have a high negative impact. The best example of this is infectious diseases, that is, global epidemics that have spread around the world. Global epidemics have various characteristics, spread rapidly to very large masses and cause fatal consequences, especially for human health. Therefore, at this point, in order to overcome the encountered risks with minimum damage, businesses should closely follow the technological developments especially in crisis periods and apply the necessary technology and innovation management processes effectively [5,6].

In this context, in this study, some suggestions are presented on the importance of technology and innovation management in crisis periods, the problems experienced in this period and taking necessary measures against these problems. In the second part of the study; technology, innovation, technology management and innovation management concepts are explained. In the third chapter, technology and innovation management in times of crisis and the problems encountered and suggestions in this process are in- 
cluded. Finally, in the fourth part, there is the conclusion and recommendations part of the study.

\section{TeChnOlogy And InNOVATion Management}

Technology and innovation management is both a technical field and a discipline. In this section, there are important subheadings about technology and innovation management. When the literature is scanned, it is seen that there are different definitions and approaches on technology and innovation management [7]. In Table 1, these approaches are summarized.

Table 1 Approaches to Technology and Innovation Management

\begin{tabular}{|c|c|c|c|}
\hline $\begin{array}{l}\text { Refe- } \\
\text { rence }\end{array}$ & Year & Author & Proposal \\
\hline [8] & 2000 & Dogson & $\begin{array}{l}\text { New product development } \\
\text { R\&D management } \\
\text { Technology strategy } \\
\text { Commercialization } \\
\text { Technological collaboration } \\
\text { Operations/Production } \\
\text { Organizational learning } \\
\text { Creativity } \\
\text { Complexity } \\
\text { Risks }\end{array}$ \\
\hline [9] & 2005 & $\begin{array}{l}\text { Tidd et } \\
\text { al. }\end{array}$ & $\begin{array}{l}\text { Strategic approach } \\
\text { Strategic learning } \\
\text { Setting effective external } \\
\text { linkages } \\
\text { Managing internal process } \\
\text { Creating innovative new firms }\end{array}$ \\
\hline [10] & 2006 & $\begin{array}{l}\text { Adams } \\
\text { et al. }\end{array}$ & $\begin{array}{l}\text { Management of inputs } \\
\text { Knowledge management } \\
\text { Innovation strategy } \\
\text { Organizational culture and } \\
\text { structure } \\
\text { Portfolio management } \\
\text { Project management } \\
\text { commercialization }\end{array}$ \\
\hline [11] & 2008 & Shane & $\begin{array}{l}\text { Development and introduction } \\
\text { of new products } \\
\text { Management and organization } \\
\text { of innovation } \\
\text { R\&D project selection } \\
\text { Portfolio management } \\
\text { Technology and innovation } \\
\text { strategy } \\
\text { Intellectual property and } \\
\text { innovation } \\
\text { Technology-based } \\
\text { entrepreneurship } \\
\text { Financing of innovation }\end{array}$ \\
\hline [12] & 2012 & $\begin{array}{l}\text { Lopes } \\
\text { et al. }\end{array}$ & $\begin{array}{l}\text { Organizational strategy } \\
\text { Project management } \\
\text { Knowledge management } \\
\text { Product management } \\
\text { Types of innovation } \\
\text { Technological innovation } \\
\text { Open innovation }\end{array}$ \\
\hline
\end{tabular}

\section{A. Technology}

Technology is defined as an information field created by researching construction techniques and vehicles related to an industrial field and an application realized in order to obtain commercial value [13]. Technology is a physical product that generates information and value, and a non-physical service or output. In addition, technology contributes to a faster and higher quality product at a lower cost. Technology is an important resource for everyone and provides a competitive advantage especially for businesses [14].

\section{B. Technology Management}

Technology management includes the development, implementation, planning, control and coordination of technological tools to determine the strategic and operational goals of enterprises and to achieve these goals [15]. The concept of technology management includes the concepts of product and process development, the strategies of businesses, product development activities, process renewal and development method, technology transfer, change management and technological change [13]. In short, the technology management process consists of determining, selecting, acquiring, using and protecting technology [16]. Figure 1 shows Gregory's technology management process.

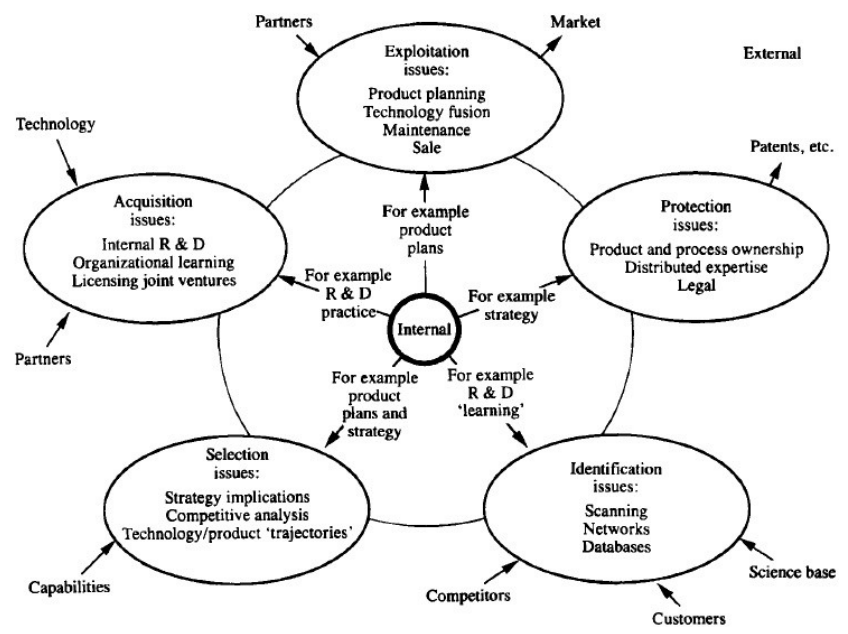

Fig. 1 Technology Management Process [16]

In summary, technology management aims to answer the following questions:

- How are technology policies and strategies developed?

- How to benefit from existing technologies?

- How to keep track of market and technology changes to ensure competitive edge?

- How is technology produced?

- How is technology protected?

- How to buy new technologies?

- How are technologies that will contribute to business processes evaluated and selected?

- How is technology transferred?

- How are technology producers managed? 
- How are technology assets integrated and used effectively?

Technology management provides guidance on issues such as the combination of management and technique, the determining technology and investment method for businesses to compete, the way technology is produced, developed and marketed, how the organizational structure is changed according to new technological developments and the competitive strategy to follow with current technology.

\section{Innovation}

The concept of innovation is the state of making changes in the structures, strategies, management processes and administrative affairs of businesses. It is the application of a new product, idea, service or process in the business processes of the business. In addition, innovation refers to the change in different business processes and services. It is the process of generating ideas and designing technology for a product that has never been applied before. Innovation, which includes commercialization, is an organizational process from the creation of the idea to economic income. Reveals new ideas in solving any problem and implements these ideas in the market. Innovation is the transformation of an idea or knowledge into economic and social benefit in any field [18].

Innovation deals with finding a new management approach, commercialization, information processing methods and applying them. It is a tool for entrepreneurship. It enables new ideas to be transferred to a marketable product or service in the market. Innovation is actually a renewal process that businesses or organizations experience in order to adapt to environmental changes [19]. In Figure 2, the steps of the innovation process are given.

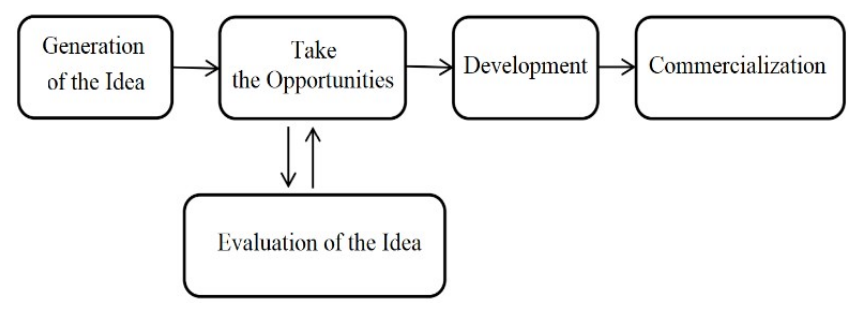

Fig. 2 Innovation process [20].

Innovation has social and organizational dimensions. The social aspect of innovation is to increase the quality of life and welfare of the society, and its organizational aspect is that competition has a process, and it provides to integration into the problem solving process [21].

\section{Innovation Management}

Innovation management plays an active role in providing companies with a sustainable competitive advantage and has a strategic understanding. A data source is required for this understanding to begin and apply. It is possible for businesses to use these resources effectively by developing and managing innovative ideas, services or products [19].
Innovation management activities fall under four categories:

- technical integration that integrates technology and markets to meet customer demands,

- the innovation process in which interdepartmental cooperation and cross functional activities are effective,

- strategic technology planning where projects for technology or competence development are envisaged,

- the business development process in which innovation by organizational change are developed, or that developed by innovations.

In summary, innovation management includes the elements of creating an innovation strategy, generating new ideas, prioritizing and selecting ideas, implementing selected ideas, and involving employees in the whole process [22-24].

\section{TeChNOLOgy AND InNOVATion MANAGEMENT IN Times Of CRISIS AND PROBLems ENCOUNTERED IN THIS PROCESS}

Businesses and societies have to develop new strategies in the face of technology change. However, this process takes place in a troublesome and difficult way because there are too many variables and constraints. Especially in times of crisis, these processes create more problems. Therefore, threats, risks and problems that may be encountered in technology and innovation management applied in crisis periods should be determined in advance and necessary interventions should be made at an early stage. For example, businesses established for commercial purposes need to consider the customer and the industry in order to provide quality products or services. This is only possible with an effective technology and innovation management approach. A technology developed at an unexpected moment will cause the habits of the past to be seriously changed. At this point, the culture of being ready for technology and innovation and adopting this issue is important [14].

Since technology and innovation management is a very broad concept and an interdisciplinary subject, businesses experience some problems in this process, as in other management processes. It is possible to list these problems as follows [25]:

- Lack of knowledge

- Lack of resources

- Use of important resources in different projects

- Experiencing disciplinary problems

- Managers not taking responsibility when making particularly difficult decisions

- Weak cooperation culture in institutions

- Incompatibility between staffs

- Experiencing cultural differences

- Experiencing ideological or differences of opinion

- Communication problems

- Problems in technology supply

There are some difficulties in innovation management, such as not being able to determine how innovation is 
formed or developed, the way of organizing for innovation and how the innovation will interact with the organization. The reason for these difficulties; innovation is a subject that focuses on fixed products and has defined boundaries, failure to centralize the innovation organization and the innovation processes consist of different subjects [26].

In general, the problems encountered in technology and innovation management are grouped under main headings below and the contents of each are given in items [14].

a) Problems Experienced in Technology Identification and Selection Step

b)Problems Encountered in the Technology Planning Step

c) Problems During Stakeholder Meetings

d)Problems During the Application of Technology Transfer

e) Problems Emerging from Insufficient Abilities (Human and Financial)

f) Problems Emerging from Ineffective Management

a) Problems Experienced in Technology Identification and Selection Step

- Wrong technology choice

- Inability to meet the needs due to the incompatibility of the determined technology with the infrastructure

- Perceiving the complexity of the specified technology by the customer or the user

\section{b) Problems Encountered in the Technology Planning} Step

- Not serving the user's needs

- Not taking part in the planning process

- Being indifferent to the technology to be acquired

- Being indifferent to the information, product or service to be obtained

- Exaggeration of technological capabilities

- Incorrect estimation of printouts

- Transferring technology by wrong means

c) Problems During Stakeholder Meetings

- Educational and cultural differences on both sides

- Differences in approach and strategy during the interviews

- Distrust among stakeholders

- Inconsistency in goals and objectives

- Conflict in pricing and marketing strategies

- Unrealistic time constraints to reach the goal

d) Problems During the Application of Technology Transfer

- Lack of experience of managers

- Obtaining technology-related documents incomplete

- Lack of achieving quality targets

- Lack of coordination in accessing materials for technology use

- Low quality and high cost in the materials reached

- Whether technology is monitored effectively or not e) Problems Emerging from Insufficient Abilities (Human and Financial)

- The client's lack of experience and skills

- Lack of knowledge of the personnel involved in the process

- Not being open to new systems

- Lack of skills for technology internalization

- Communication problems between stakeholders

- Lack of report request

\section{f) Problems Emerging from Ineffective Management}

- Lack of support in management

- Inadequacy of senior management in intermediary role in all steps related to technology

- Errors, inadequacies and differences in working methods

- Inadequacy in putting current technologies into a competitive environment

- Inability of management to recognize and authorize staff with whom it works

Considering all these problems, businesses should understand product requirements, must be manufacturable products and provide skilled processing technologies in order to bring products to market faster and more cost-effectively. At this point, products and services wealth should be provided, especially in order not to be adversely affected by crisis periods. Because product and service wealth is a possible strategy to increase an organization's competitiveness. However, companies cannot effectively utilize production personnel or change their production practices to support process and product innovation [27].

\section{CONCLUSION AND RECOMMENDATIONS}

In the study, a detailed examination was made about technology and innovation management in crisis periods, management processes and the problems encountered in this process and some suggestions were presented. The results of the analysis showed that the rapid change and development experienced in technology significantly affect the business processes of the enterprises. In addition, the processes of defining, identifying, obtaining and protecting technology (technology management) must be carried out effectively and completely. Especially in times of crisis, this issue is much more important. The more effective and careful technology and innovation management is carried out in times of crisis, the more at requested time, the desired amount, lower cost and better quality of businesses can produce their products. In addition, with an effective technology and innovation management approach, enterprises can accurately predict the developments in the field of technology and thus plan their investments and production according to the data they have. The important point here is that, for a successful technology and innovation management, the people in the technological planning team should organize in cooperation, brainstorm periodically and adjust time management well. 
Businesses should not be afraid of using advanced and new technologies, they should be more aggressive in technology transfer and use. Technology and innovation management organizes the group and ensures that the work is done more effectively, productively and widely. It is important that technology management activities take place in the light of the important results and suggestions mentioned above, in terms of being affected at a minimum level from possible adverse situations.

Finally, more scientific research should be done to clearly reveal the difficulties or problems encountered in the process. Different technology and innovation management approaches should be developed to overcome all problems, especially in times of crisis. In addition, a system can be developed to organize, manage, analyze and monitor technology and innovation management activities in a more dynamic and applicable manner. In addition, technology and innovation management should not only be adopted by individuals and institutions, but also countries should include this issue in their domestic policies.

\section{REFERENCES:}

[1] Davutoğlu, T. T. (2019). Yerel belediyelerde teknoloji yönetimi: Beyoğlu Belediyesi örneği (Master's thesis, İstanbul Ticaret Üniversitesi).

[2] Düşükcan, M., \& Kaya, E. Ü. (2003). İşletmelerde Bilgi Teknolojilerinin Kullanılma Yerleri. Firat Üniversitesi Doğu Araştırmaları Dergisi, 1(3), 33-37.

[3] Karadal, F., \& Türk, M. (2008). İşletmelerde teknoloji yönetiminin geleceği.

[4] Kaya, P., Erol, T., \& Ozbilgin, I. G. (2017). Definıng A Technology Management Framework Within A Defense Enterprise. Journal of Management Marketing And Logistics, 4(3), 301-309.

[5] Karl, H., \& Tanyas, M. (2020). Pandemi Durumunda Tedarik Zinciri Risk Yönetimine İlişkin Öneriler. İstanbul Ticaret Üniversitesi Sosyal Bilimler Dergisi, 19(37), 174-190.

[6] Deloitte. (2020). COVID-19 Managing supply chain rsik and disruption.

[7] Arciénaga Morales, A. A., Nielsen, J., Bacarini, H. A., Martinelli, S. I., Kofuji, S. T., \& García Díaz, J. F. (2018). Technology and innovation management in higher education-Cases from Latin America and Europe. Administrative Sciences, 8(2), 11.

[8] Dogson, M., Gann, D., \& Salter, A. (2000). The management of technological innovation. Hildalgo, Antonio and Albors, Jose (2008). Innovation management techniques and tools: a review from theory to practice. $R \& D$ Management, 38(2), 113-127.

[9] Tidd, Joe, John Bessant, and Keith Pavitt. (2005). Managing Innovation: Integrating Technological, Market and Organizational Change. West Sussex: John Wiley \& Sons. ISBN 0-470-09326-9.
[10] Adams, Richard, John Bessant, and Robert Phelps. (2006). Innovation Management Measurement: A Review. International Journal of Management Reviews 8: 21-47. [CrossRef]

[11] Shane, Scott. (2008). Handbook of Technology \& Innovation Management. New York: Wiley \& Sons. ISBN 978-1-4051-2791-2.

[12] Lopes, Ana P., Kumiko O. Kissimoto, Mário S. Salerno, Fernando J. B. Laurindo, and Marly C. Carvalho. (2012). Innovation Management: A Literature Review about the Evolution and the Different Innovation Models. Paper presented at XVII International Conference on Industrial Engineering and Operations Management, Guimarães, Portugal, July 9-11.

[13] İnce, M., Oktay, E., \& Gül, H. Bilgi ve Teknoloji Yönetimi Açısından Teknoparkların İşlevleri Ve Kahramanmaraş Sanayi Profili Açısından Bir Değerlendirme.

[14] Çakmak, T., Kılıç, A., \& Tunçay, A. (2012). Teknoloji Yönetimi Kilavuzu. İstanbul Sanayi Odası Yayın.

[15] Tekin, M., \& Göral, R. (2010). İşletmelerde Stratejik Teknoloji Yönetimi Ve Sürdürülebilir Rekabet Üstünlüğü İlişkisinin Belirlenmesi Ve Otomotiv Yan Sanayi İşletmeleri Üzerine Bir Araştırma. Sosyal Ekonomik Araştırmalar Dergisi, 10(19), 292-320.

[16] Gregory, M. J., (1995). "Technology Management: A Process Approach", Proceedings of the Institute of Mechanical Engineers, s.350

[17] Yıldız, E. (2007). Teknoloji Yönetimi. Yayınlanmamış yüksek lisans tezi, Kahramanmaraş.

[18] Aydın, A. Ö., \& Bekmezci, M. (2020). Stratejik Yönetim Anlayışında Yenilik Ve Yenilik Yönetiminin Örgütler İçin Rekabet Üstünlüğ̈̈ Sağlamadaki Etkisine Yönelik Değerlendirme. Türkiye Mesleki Ve Sosyal Bilimler Dergisi, (3), 86-106.

[19] Gürsel, Ü. (2017). Örgütsel bağllllk ve yenilik yönetimi ilişkisi: Mutfak personeli üzerine bir araştırma (Master's thesis, Kırklareli Üniversitesi Sosyal Bilimler Enstitüsü).

[20] Luecke, R. (2011). İş Dünyasında Yenilik ve Yaratıcılık Çev. Turan Parlak. Ġstanbul: Türkiye GGG Bankası Kültür Yayınları.

[21] Bakır, A. A. (2016). Innovation management perceptions of principals. Journal of Education and Training Studies, 4(7), 1-13.

[22] Ventura, K., \& Soyuer, H. (2016). Innovation Management and Knowledge Based-Innovation Approach in Research and Development-Marketing-Production Integration. Ege Akademik Baklş Dergisi, 16(5), 41-50.

[23] Goffin, K. ve Rick, M. (2005) Innovation Management: Strategy and Implementation using the Pentathlon Framework, Palgrave Macmillan

[24] Drejer, A. (2002). Situations for innovation management: towards a contingency model. European journal of innovation management.

[25] Calp, M. H., \& Doğan, A. (2015). Technology Management Process and Encountered Problems in Organizations. Roma, Second Intl. Conf. on Advances in Management, MES2015, 8, 13.

[26] Nambisan, S., Lyytinen, K., Majchrzak, A. ve Song, M. (2017). Dijital İnovasyon Yönetimi: İnovasyon yönetimi araştırmasını dijital bir dünyada yeniden keşfetmek. Mis Quarterly, 41 (1).

[27] Arana-Solares, I.A., Ortega-Jiménez, C.H. ve Alfalla-Luque, R. (2019). Üretim stratejisine ve teknoloji yönetimi-performans ilişkisine müdahale eden bağlamsal faktörler. Uluslararası üretim ekonomisi dergisi, 207, 81-95. 